\title{
A THEMATIC AND COMPARATIVE \\ CRITIQUE
}

Jason Chuah

\begin{tabular}{|c|c|c|c|}
\hline BACKGROUND TO THE RESEARCH PROJECT & 1.01 & $\begin{array}{l}\text { Judicial supervision in the } \\
\text { reorganization efforts }\end{array}$ & 1.23 \\
\hline PROJECT METHODOLOGY & 1.08 & Ipso facto stipulations & 1.32 \\
\hline Prefatory observations & 1.10 & $\begin{array}{l}\text { Assignment of executory contracts } \\
\text { Value extraction }\end{array}$ & $\begin{array}{l}1.44 \\
1.59\end{array}$ \\
\hline LIMITS ON ASSUMPTION OR DISCLAIMING & & & \\
\hline OF EXECUTORY OBLIGATIONS & 1.19 & CONCLUSION & 1.61 \\
\hline
\end{tabular}

\section{BACKGROUND TO THE RESEARCH PROJECT}

This peer-reviewed and edited collection of chapters sets out to detail and analyse how the different national insolvency law systems treat the matter of executory contracts. When a business becomes insolvent, that does not necessarily bring an end to the contracts that business had previously entered into but are pending performance. While the subject matter is not new, more and more jurisdictions are having to continue to evolve and reform their legal responses to the subject matter in the light of the practical and conceptual difficulties a less than flexible approach throws up. There are no easy solutions, it would appear.

Many systems of law provide for the right of the trustee in insolvency to assume or disclaim a pre-existing contract. That right is controversial because it creates an anomaly in that the trustee appears to have been imbued with the right to speculate on the rise and fall of the relevant market and make a decision on the contract depending on which the market is heading. That, is seen by some, as flying in the face of common commercial sensibilities. After all, most legal systems do not allow a seller (for example) to speculate at the buyer's expense when they are in possession of a binding agreement.

On the other hand, policy makers are genuinely concerned that if such a right were not to exist, that would inevitably lead to much economic waste. 
Moreover, speculation may or may not always be a relevant factor - since the market price in question may be quite stable or there are other factors to assume or disclaim the contract.

1.04 The philosophy behind this project is that lessons could be learnt from both developing and developed countries, and from small and large countries. The aim is to identify the key supporters, the stakeholders and the pull-push factors driving the agenda for reform. There will also be an analysis of the theoretical underpinnings of how the different insolvency law systems treat executory contracts and, where appropriate, policy recommendations are suggested.

1.05 In this preambular chapter, we shall draw some general observations from the country reports and comment on some of the main challenges faced by the laws of the many nations under study. There are elements in our approach in this chapter which might loosely be classed within the functional method ${ }^{1}$ often adopted in comparative law analysis. We draw from the evidence provided by the country reports to help ascertain the impact or effects of the legal rules on the treatment of executory contracts in insolvency. However, this chapter also engages in a rule-based comparative analysis in an attempt to locate and identify the different rules and their construction within their domestic contexts. The purpose of this conjoined approach is to provide practitioners and policy makers with both a cultural and legal perspective of the research.

1.06 The functional method, of course, is not without critics; ${ }^{2}$ however for practitioners and policy makers, it remains a useful (albeit possibly narrow) method for looking at discrete aspects of good or poor practice. For a monograph which is intended to stimulate discussion amongst policy makers

1 There is of course a great deal of literature on the method: see Ralf Michaels, "The Functional Method of Comparative Law', The Oxford Handbook Of Comparitive Law (OUP 2006) 339 who provided the following list. See, e.g., for the United States, John C. Reitz, How to do Comparative Law', (1998) 46 AJCL 617; Mathias Reimann, 'The Progress and Failure of Comparative Law in the Second Half of the Twentieth Century', (2003) 50 AJCL 671; for France, Marc Ancel, 'Utilité et méthodes de droit compare. Eléments d'introduction générale à l'étude comparative des droits', (1971) 23 RIDC 933; idem., 'Le problème de la comparabilité et la méthode fonctionnelle en droit comparé, Festschrift für Imre Zajtay (J.C.B. Mohr Tubingen 1982), 1; for England, Hugh Collins, 'Methods and Aims of Comparative Contract Law', (1991) 11 OJLS 396; Peter de Cruz, Comparative Law in a Changing World (2nd edn, Routledge-Cavendish 1999) 230; for Germany, Hein Kötz, 'Comparative Law in Germany Today', (1999) 51 RIDC 753; for Scandinavia, Michael Bogdan, Comparative Law (Springer 1994), 59-60; for a socialist perspective, Imre Szabó, 'Theoretical Questions of Comparative Law', in Imre Szabó and Zoltán Péteri (eds), A Socialist Approach to Comparative Law (1977), 9, 36-38; for rise and fall in Italy, Pier Giuseppe Monateri, 'Critique et différence: Le droit comparé en Italie', (1999) 51 RIDC 989.

2 See generally Ralf Michaels (ibid.). 
and professionals, aspects which borrow from the functional method might be justifiable on the grounds of convenience, focus and clarity. That said, it should be emphasised that in this chapter dealing with comparative analysis we are not merely concerned with functions of the rules but also on legal argument, interpretation and policy considerations.

An important facet of this Introduction is that as the stress is on legal themes, the subject of executory contracts would be explored without making the fine, technical distinctions between administration and liquidation. The issue of executory contracts in either of these contexts has been very ably discussed in our national reports.

\section{PROJECT METHODOLOGY}

The chapters are grouped somewhat loosely based on the legal family they belong to - namely, civil law systems, common law systems, and hybrid systems. The contributors are asked to pay close attention to the following themes in their chapters:

\section{Section 1}

- Which hybrid and formal procedures are available under current legislation to a company in financial or economic distress?

- Which are the requirements for triggering those procedures? If 'insolvency' is one of these requirements, is this notion provided for by the law? Who can file for these procedures (e.g., debtor only, creditors only, both and/or third parties)? Who usually institutes them?

- Do companies rely on out-of-court proceedings (e.g., direct negotiations with creditors)? Have these procedures been regulated by the legislators?

- Are there any other remarkable features of the domestic legal regime, which are relevant to mention in the introduction?

Section 2

- For each of the procedures mentioned in the first section, describe the treatment of executory contracts provided by the law. When does pacta sunt servanda (contracts shall be kept) apply? When does the principle of paritas creditorum (equal treatment of and distribution among creditors) prevail? 
Do special rules apply in the insolvency context? Are executory contracts deemed to be assumed or rejected? If statutory assumption or rejection are imposed by the law, what are the consequences for the parties?

Do rules change if the debtor is either the performing or the non performing party? Do rules change depending on the nature of the procedure (either reorganisation or liquidation)? Do special rules apply depending on the nature of the contract, ${ }^{3}$ the counterparty (public or private), its duration, or its importance for the survival of the distressed business? Can contracts be partially assumed or rejected? If no special rules apply, which is the general treatment provided in the law?

- For each of the procedures mentioned in the first section, describe the statutory treatment in insolvency law of contractual remedies agreed by the parties in solvent times.

Are termination and acceleration clauses, sometimes referred as ipso facto clauses, enforceable in your country? To which extent (e.g., case-law and definition of ipso facto clause)? Is the same solution adopted with reference to all the procedures mentioned in the first section?

Are other clauses with similar effects ${ }^{4}$ valid and enforceable under current legislation? What is the courts' attitude towards these clauses?

- Are there any other remarkable features of the domestic legal regime, which are relevant to mention in this section?

Section 3

The project team was asked to consider:

- Any major reforms since the year $2000 ?^{5}$

- What is the impact of these reform (if any) on the treatment of executory contracts? Which was the position of the government, how it changed throughout the reform debate and/or years, what contributed to those changes (e.g., economic crisis, EU regulations, etc.)?

- Are new proposals of reform of the existing insolvency framework being explored?

3 Personal; Sale, hire-purchase and finance lease; Utilities; Labour; Pension; Financial.

4 Close-out nettings; Flip clauses; Conditional rights; Penalty Provisions.

5 Before the enactment of the Council Regulation (EC) 1346/2000 on insolvency proceedings [2000] OJ L 160 but shortly after the enactment of the UNCITRAL Model Law on Cross-Border Insolvency 1997. 
In this chapter, the editor has tried to avoid making fine distinctions between

liquidators, administrators, insolvency practitioners, monitors, official receivers, office holders, etc. Fine distinctions would not serve our general comparative law purposes given that different jurisdictions will have different 'officers' to deal with insolvent or virtually insolvent companies. Our object is to assess in a broad brush manner the different approaches in law and policy to how executory contracts are treated in cases of 'insolvency'. So too the term 'insolvency' would not be deeply discoursed in this text.

\section{Prefatory observations}

An immediate general observation might be made that in established common law systems, there is a good deal of disputations over what some might term the minutiae of the principles. In the US for example case-law seems to be divided between the right approach or test to identify what constitutes executory contracts in insolvency. Some courts prefer the so-called material breach test, first propounded by Professor Countryman ${ }^{6}$ while others opt for the functional test. In the US prior to these two tests, commentators have tried to reason that executory contracts are property of the estate and therefore could simply be dealt with as the trustee sees fit - disclaim or assume. However, such an explanation is defective in that there are knock-on effects which could not be ignored. After all, the corporate entity in insolvency must pay for the rights it gives away or conversely, pay damages for rejecting or abandoning the contracts.

The Countryman test defines an executory contract as an agreement where 'the obligations of both the bankruptcy and the other party are so far unperformed that the failure of either to complete performance would constitute a material breach excusing performance of the other'. On the other hand, the functional test which works 'backward from an examination of the purposes to be accomplished by rejection, and if they have already been accomplished then the contract cannot be executory. ${ }^{7}$

However, although there is some fretting over the definition of executory contracts, the approach in England is less conceptually oriented when contrasted against the US context. The UK Insolvency Act 1986 allows the trustee to disclaim an onerous property without needing judicial sanction. ${ }^{8}$

6 V. Countryman, 'Executory License Agreements in Bankruptcy', 57 Minn. L. Rev. 439, 460 (1973).

7 In re Magness, 972 F.2d 689, 693 (6th Cir. 1992); see too Jay Lawrence Westbrook, 'A Functional Analysis of Executory Contracts', (1989) 74 Minn. L. Rev. 227.

8 Insolvency Act 1986, s 178. 
The emphasis is on the liquidator's judgment as to what is onerous, and not on any lexical discourse about the term 'executory'.

1.13 Some civil law systems in Europe tend to have specific rules relating to different types of 'executory contracts' - in Italy, The Netherlands, Finland and Spain, to name a few, there are special rules for leases, employment, real property and continuous contracts etc. where a generic definition or description of what is executory would not be sufficient. There are countries, like Finland, where a distinction is also made between divisible obligations and indivisible obligations.

1.14 In contrast, countries like Slovenia actually make an explicit definition of the term 'executory contract' in their insolvency law - the Slovenian Insolvency Act expressly defines a mutually unfulfilled bilateral contract (executory contract) as a bilateral contract which has been concluded prior to the initiation of insolvency proceedings, and whereby, prior to the initiation of insolvency proceedings: (i) neither the insolvent debtor nor the other party to the contract have performed their obligation on the basis of the contract, or (ii) neither of the parties has fully performed such obligations. ${ }^{9}$ Swiss law also defines executory contracts but is more general - the Insolvency Law is only concerned with 'synallagmatic contracts which had not or had only partially been fulfilled at the time of the opening of the bankruptcy'. By means of elimination, other forms of contractual obligations, such as a unilateral promise to provide services or money, would be excluded from the scope of 'executory contracts'. Other jurisdictions adopt the meaning of the term as provided for by their civil commercial law. In Greece for example the insolvency law simply adopts the meaning as stated in the Greek Civil Code which defines executory contracts as those that impose future rights and obligations for both contractual parties. Cyprus adopts a similar approach but places some emphasis on the failure to perform wholly the contract. Although reference is usually made in these systems to general civil law, the approach is quite pragmatic and courts do not engage in a theoretical questioning of whether a particular contractual relationship was executory or not. That matter of fact approach is also adopted in countries such as Germany, Denmark, Bulgaria, Turkey and Albania. Yet other jurisdictions do pay much attention to the conceptual definition of 'executory contracts'. In France, for instance, although there is no jurisprudence taking the sort of conceptual definitions applied by the US courts, French case law and academic commentaries suggest that it is important to identify first the performance or obligation which is characteristic of the contract. Then it follows that if the relevant characteristic obligation of a

9 See Chapter 20. 
contract has already been performed before the insolvency procedure is opened, the contract would not be considered to be executory. ${ }^{10}$ This approach appears closer to the American material breach test than the functional test, but cannot be said to be similar. The French approach starts with the construction of the agreement to ascertain the obligation on which the entirety contract sits.

In Latin America, the picture too is not uniform. Although most jurisdictions have some prescribed rules dealing with executory contracts, there is often a pragmatic acceptance as to what the term 'executory contract' means. For instance, the Panamanian legal system simply assumes that these are contracts which have not yet been performed and older legislation renders them unenforceable as soon as insolvency occurs. ${ }^{11}$ Some other legal systems have developed a jurisprudence based on civil commercial law as to the description (not necessarily a legal definition) for the term. In Chile, for example, insolvency law practitioners and commentators take the view that executory contracts can include promises to contract but seem to exclude contracts where one party had completed performance whilst the other had not. ${ }^{12}$ In Chile, an executory contract will lead to different implications depending on whether the insolvency procedure in question is an action for reorganisation or liquidation. Likewise, in Argentina, there are specific rules for specific types of executed and executory contractual obligations in insolvency. Broadly speaking, contracts might be classified into three groups: (a) contracts that are terminated; (b) contracts that are continuated or continuing contracts; and (c) contracts which are suspended, pending a determination as to whether they will be resolved or continued through their 'assumption' by the liquidator. Category (c) includes contracts where either party's obligations have not been fully performed. ${ }^{13}$ Brazilian law takes a similar line whereby executory contracts can include those where neither party has fully performed their contractual obligations.

The picture is similar in Asia - the PRC, while not expressly defining executory contracts, in providing for the liquidator's powers makes a distinction between those contracts with an obligation or part thereof to be performed by the insolvent entity and those to be performed by the other party. That appears also to be the approach taken by the common law based jurisdictions under study in this project such as Singapore, Bangladesh, India, New Zealand and Australia. These countries do not provide any explicit and

10 See Chapter 12.

11 See Chapter 18, p 360.

12 See Chapter 7, pp 140-141.

13 See Chapter 3 generally. 
detailed definition of 'executory contract', content simply with the notion of contracts with unperformed or incomplete obligations. There is no direct engagement with theory, like the US courts have been concerned with.

1.17 This leads us to the question as to whether having a definition of 'executory contract' in the context of insolvency is useful. At one level the approach should largely be about what to do with contracts calling for future performance and an overly technical characterisation of an 'executory contract' would only serve to defeat the object of the law. Legalism perhaps is not the best approach to adopt when so much of whether a future obligation should or should not be disclaimed is already a matter of business judgment.

1.18 In this context it is worth reflecting on the notion of 'adversarial legalism'; some scholars have argued that 'adversarial legalism' has in modern legal culture and history emerged as a distinctive American legal style. ${ }^{14}$ In the context of defining the executory contract for the purposes of dealing with the liquidator's power to disclaim onerous contracts, we might be able to suggest that given that in the US, such disclaimers may routinely be challenged judicially, a particularly legalistic style which emphasises detailed, prescriptive rules, substantial transparency in legal tests and formulated principles has developed. It is undeniable in the US and parts of the common law world, normative language (such as 'you can disclaim an onerous executory contract') has to some appreciable degree been coloured now by conditionalities typified by definitions.

\section{LIMITS ON ASSUMPTION OR DISCLAIMING OF EXECUTORY OBLIGATIONS}

1.19 It is not proposed to go into depth on the subject here, given the very full explanations provided for in our country reports. The purpose here is to delineate the circumstances under which the different legal systems control the assumption or disclaiming of the executory contract following insolvency.

1.20 It might be said the legal right to assume or disclaim executory obligations is to some extent shaped by the modern tenet held in both common law and civil law countries that an insolvency event does not bring an end to the contractual relationships of the insolvent. That said, as regards assumption of the contract, in the common law tradition, it is conceivable though not commonplace that

14 See generally Robert A. Kagan, Adversarial Legalism: The American Way of Law (Harvard University Press 2001). 
an insolvency event might be construed as an anticipatory breach which could then bring an end to the contract. ${ }^{15}$

On the whole the right to assume or disclaim an executory contract is a matter of private law ensuring that the liquidator or office holder has the degree of control to reorganise the company. In the case of disclaiming, it is quite clear that many jurisdictions permit the office holder to decide whether to disclaim an onerous contract based on their business judgment exercised in good faith. Judicial interference is limited as is seen quite plainly in the US, Singapore, Australia, Canada, the UK, Denmark, Turkey, Germany, France, Chile and others. However, in certain contracts, where there are important public interests at stake, the law of the land may restrict that right to assume or disclaim the executory contract. South Africa is an excellent case in point. Its political history has been such that land transfer and ownership have been highly sensitive. Its Constitutional Law hence makes it absolute that the office holder must complete the transfer of land purchased and being paid for by instalments - failure to do so would be to cause a serious injustice on those who are poor and vulnerable. Disclaiming the contract is out of the question.

There may be less weighty reasons for curbing the right to assume or disclaim contracts. In Japan, for example, our country report highlights a Supreme Court decision where unfairness was held to be a valid reason to deny the office holder from disclaiming a contract. There, a company had paid a substantial corporate membership fee to a golf club which would be refunded in ten years' time if their membership was cancelled. The company went into liquidation and the office holder purported to disclaim all contracts with the golf club and sought a refund of the fee. The court denied the company's claim because to do so would be to cause unfair consequences on the counterparty.

\section{Judicial supervision in the reorganization efforts}

Most legal systems, as we see, allow a good measure of discretion and business judgment for the office holder to decide whether it is in the creditors' best interest to assume or disclaim an executory contractual obligation. This editor is interested in examining and comparing the role of judicial supervision in this regard.

The subject of judicial supervision of course is controversial. On the one hand, 1.24 it is arguable that the decision to assume or disclaim is a matter of good 
business judgment and given the exigency of time, that discretion of the debtor should not be interfered with too easily. On the other hand, in a good number of jurisdictions the policy debate has shifted away from simply about the decision to protect creditor interest but also about the justiciability of such a decision. In matters relating to fairness and justice, it is thus contended that the discretion of the liquidator should be subject to a degree of judicial supervision. There is probably no right answer here, save the platitude that the optimal position is somewhere between the two poles.

1.25 The intention here is therefore not to look for that utopian point but simply to look at how judicial supervision should be exercised and on what grounds.

1.26 First of all, judicial supervision may actually be sought by the debtor in relation to executory contracts. In the case of Argentina, for example, in both pre-packaged reorganisation and voluntary reorganisation schemes, while the debtor is free to renegotiate the terms of the executory contract, any proposed modification must be submitted to the court for approval. ${ }^{16}$ In the latter, (called 'Concurso Preventivo'), differing levels of judicial supervision are applied depending on when the decision to modify/assume the contract is made. Where the decision is made by the office holder before the first 30 days since the opening of the Concurso Preventivo, the debtor may choose to fulfil the contract with pending reciprocal obligations. To do this, they must seek the court's approval and authorisation. The court is required to consider properly the opinion of liquidator which should be based on technical business judgment and be impartial. The court's role is thus to assess whether the decision appears to be impartial and not tempered by bad faith or manifest error of judgment. In the case where 30 days have elapsed, the third party may terminate the contract promptly or call for performance or compliance. In the first, no judicial supervision is needed. The creditor only needs to notify the debtor and trustee. In the second situation, prior judicial authorisation is required. Failure to secure judicial approval will result in the termination of the contract. ${ }^{17}$ Naturally the 30 -day threshold is a legislative compromise. However that shows that the law is not insensitive to the constraints of time and practical expediency. For clarity and certainty, if the creditor third party had taken a period of time to decide, the courts should necessarily be involved in ensuring that that decision is not unfair or impractical, and does not have too extensive a negative impact on other relationships. With the various time limits and procedural requirements, the Argentine system is one which implicitly takes the view that the lack of clarity can lead to poor, ineffectual 
judicial supervision which in turn results in poor negative restructuring or reorganisation outcomes.

It is trite to say too that a laboriously slow judicial process despite the presence of sound rules could well lead to the same negative outcomes. Indeed, our Bangladesh report highlights that proposition quite amply; although the legal rules are actually reasonably well developed having been transplanted from other parts of the common law world, the under-resourced judicial and legal system makes the judicial supervision process quite ineffectual.

Judicial supervision might also be found not when the office holder discharges their functions, but at an earlier point - the time when they are appointed. In the PRC, for example, under the Enterprise Bankruptcy Act, the appointment of an administrator needs to be approved by the court. That appointment is not always a matter-of-course exercise. An indepth level of evaluation of the competencies and qualifications of the administrator is made when the official list of administrators is drawn up by a seven person special committee of the Supreme People's Court. ${ }^{18}$ The court will decide on whether a particular administrator is appropriate for the case in question. Hence, where the case concerns wide local concerns, the court would appoint an administrator with good local experience and reputation. On the other hand, where the case concerns a large commercial entity with extensive reach, the court would look to appointing a non-local entity (usually a firm) as the administrator. ${ }^{19}$ The administrator then assumes virtually all control over the debtor and their appointment might thus be said to reflect the court's approval of their power.

That matter is exacerbated by the fact that under the 2006 Enterprise Bankruptcy Law, when the debtor (as against the creditor) files for bankruptcy, unlike many legal systems where the courts would merely take judicial notice of the filing, the PRC court has wide discretion not to accept the application on the basis that there is no case of bankruptcy. ${ }^{20}$

18 The SPC's Regulations on Appointment of Administrators in Enterprise Bankruptcy Cases (promulgated by the SPC, effective June 1, 2007), arts 10 and 11.

19 Note The SPC Regulations on Appointment of Administrators et. al. (ibid.), art 15; also Yujia Jiang, 'The Curious Case of Inactive Bankruptcy Practice in China: A Comparative Study of U.S. and Chinese Bankruptcy Law' (2014) 34 Nw. J. Int'l L. E B Bus. 559, 573.

20 See the PRC Enterprise Bankruptcy Law arts 2 and 7; also Lijie Qi, 'The Corporate Reorganization Regime Under China’s New Enterprise Bankruptcy Law', (2008) 17 Int'l Insolvency Rev. 13, 15-17. 
1.30 Indeed, scholarship on PRC bankruptcy law has argued that the extensive judicial discretion and intervention of government policies make the system less efficient than its counterparts elsewhere, such as in the US, Europe and the UK. ${ }^{21}$

1.31 In summary, it might be reasoned the role of judicial supervision while important as regards how executory contracts are to be treated in administration or liquidation, there is divergence in the policy rationale to how judicial supervision should be exercised and managed.

\section{Ipso facto stipulations}

1.32 It is widely known that ipso facto clauses are not treated uniformly between the different legal systems and this is properly borne out by the country reports. Some countries have had a fully aired debate about the matter of enforceability of such clauses; other jurisdictions have not tackled the matter from a policy perspective and have relied largely on general principles of law to deal with the issue.

1.33 Take Singapore, for example, lengthy debates at various policy and professional levels took place - the usual concerns were raised about whether ipso facto clauses which accelerate the termination of the contract would produce a deleterious effect on restructuring prospects. The discussion went on to explore whether the right provided for by these clauses should be restricted and be judicially controlled so that the management powers of the liquidator should not be unduly interfered with by the creditor who is the beneficiary of the ipso facto clause. There also appears to be some evidence, according to the Singapore report, that one reason why a good number of rescue proceedings fail in Singapore was because the company management refuses to engage in formal proceedings until the very last minute. Thus, if ipso facto clauses are unenforceable, that could perhaps induce the distressed company into starting discussions about rescue a little earlier on. However, after weighing up the pros and cons, the Singapore Government decided not to change the status quo - namely, that which mirrors the English common law position, that is to say, ipso facto clauses will remain valid. The main argument for keeping the status quo was that as a global financial and commercial hub, it would be insensible for Singapore as a small state to go its own way and adopt a different approach to that which has held sway in jurisdictions that have derived their laws from the English common law.

21 See generally Yujia Jiang, supra n. 19. 
On the other hand, Canada and Australia have taken the confident step to depart from the traditional orthodoxy that ipso facto clauses, as freely entered into contractual clauses, are enforceable subject to a careful application of the legal rules on construction of contracts. Like Singapore, debates were had as to the impact, negative or otherwise, of ipso facto clauses. Unlike Singapore, Australia and Canada decided to legislate against ipso facto clauses - Canada took the step in 2009 whilst Australia, more recently in 2016/17. The Canadian experience is a little less of a stark change than the Australian in that the Canadian courts had (in the context of large insolvencies ${ }^{22}$ ) been prepared to restrict the application of ipso facto clauses even before the law reforms in 2009. However, the matter is properly put to rest - the new law and the Australian legislation both expressly render unenforceable those ipso facto clauses which allow for the termination of contracts solely on the basis of an insolvency event if a business comes under the control of an administrator or receiver or if the company is utilising draft proposed safe harbour ${ }^{23}$ arrangements. ${ }^{24}$ In Australia, the new law also allows 'suppliers' to apply to the court for an order to terminate the contract in circumstances of 'undue hardship'. ${ }^{25}$

It is well and good for certain common law jurisdictions like Canada and Australia to take this approach - however, such reforms are themselves not without challenges, doctrinally speaking. Our Singapore report highlighted how even if ipso facto clauses are banned, creditors may argue that the insolvency event nevertheless constitutes an anticipatory breach of the contract. The common law jurisprudence on anticipatory breach is at best uncertain, and at worst, conflicting. ${ }^{26}$ Thus, for a ban to work effectively, the law should ideally also remove or limit the right to claim anticipatory breach however, the limiting of a common law general principle of contract law is not something which common law systems are generally quick to do. Having the security blanket of the status quo offered by the traditional English common law system is not necessarily a negative. Noting the case of Bangladesh, it is clear that the corporate insolvency law system in Bangladesh is very much in its infancy and having its roots in the English common law tradition means that there should not at least be a lacuna should challenges around ipso facto clauses surface.

22 Those falling within the scope of the Companies' Creditors Arrangement Act 1985.

23 It should be noted that unlike the US Chapter 11 scheme, the Australian Safe Harbour is not a Court-controlled process. As such, there is no scope for cramming down dissenting creditors or granting super-priority status for fresh debt.

24 Australian Government Productivity Commission (n150), 32-33, 360-365.

25 Ibid.

26 As the Singapore case of STX Mumbai [2015] SGCA 35 demonstrates. 
1.36 The Australian response however is understandable. The events leading up to the reform were significant. As is pointed out by our Australian report, the fallout from the collapse of One.tel primarily because their suppliers, Telstra and Optus, promptly exercised their rights under their ipso facto clauses and that quite peremptorily brought down the company in hours. Reform driven by real and significant events is of course understandable; however, it is also important to beware of any knee jerk response.

1.37 In jurisdictions where there is no specific provision for ipso facto clauses, one should not conclude too quickly that there is a vacuum in the law. Such a provision or at least, the utility or use of such a device may actually be dealt with by general principles. However, that reliance on general principles to resolve disputes and controversies is sometimes tempered by regard to the controversial nature of $i$ sso facto clauses globally.

1.38 Take the PRC, for example, ipso facto clauses are not specifically recognised or unrecognised in law. Article 93 para 2 of the PRC Contract Law permits parties to agree to the conditions under which either party may bring an end to the contract. It is immediately obvious that although article 93 does not explicitly refer to ipso facto clauses, it could be extended to cover such clauses. There are also procedural constraints to the invoking of such a right as we see in our PRC report. Proper notice of the condition being met must be given by the person seeking to terminate the contract. ${ }^{27}$ Moreover, the respondent may challenge the legitimacy of the purported termination in court or arbitration. In short although technically speaking such clauses do not run foul of the law, in adjudicating their legitimacy the courts would be keen to ensure that workers' rights are properly protected ${ }^{28}$ and that the general rationale of the Enterprise Bankruptcy Law to confer sufficient discretion and management control on the administrator should not be defeated. ${ }^{29}$ It is quite clear from the various commentaries on the subject that the controversy surrounding ipso facto clauses has also surfaced in the PRC. Consequently, no PRC court or arbitration will ignore the potency of such clauses in restricting the administrator's powers to continue with the contractual relationships in the commercial interest of the company and the creditors.

1.39 Noting that the PRC's insolvency system was only recently reformed in 2006 and despite the fact that commentators in the PRC have clearly and early on picked up on the problem of executory contracts and ipso facto clauses, one

27 See Contract Law of The People's Republic of China 1999, art 96.

28 See $\mathrm{p} 161$.

29 See $\mathrm{p} 167$. 
might be critical that there is no specific treatment of the subject in the law reform. However to argue that would be perhaps unfair.

As is obvious in the case of Australia and Singapore, the matter is not resolved

- not only are there far too many uncertainties about the impact of an outright ban, problems too abound if such clauses are expressly recognised and enforced. Perhaps the matter, as far as some countries are concerned, is best left untreated at present while there is yet global consensus as to the optimal solution. That seems to be the case with countries like the PRC that have introduced reform to insolvency law in recent times such as Turkey, Croatia, Russia, Lithuania etc. In the case of Russia, there is little provision for even executory contracts more generally.

It might also be suggested that despite the lack of direct legal treatment on the subject of ipso facto clauses in these countries, because of the lacuna regard may be had to public policy. In Lithuania, for example, our report tells us that ipso facto clauses are not banned and their enforcement has not, from available evidence, led to any unjust economic difficulties for all concerned. However, as is common with many jurisdictions the validity of the clause could ultimately be tested against the meter bar of public policy. The question is thus whether it might be argued that in a case like One.tel in Australia which led to the loss of several thousand jobs and many contracts being entirely demolished, the exercise of ipso facto rights might be ruled to be illegitimate under public policy considerations. From an English law standpoint, the reliance on public policy considerations in a matter which is best legislated by Parliament would clearly not be encouraged.

There is also, in some of those countries without an explicit framework for ipso facto clauses, acknowledgement that such clauses are commonplace and would thus be permitted at least in practice, if not expressly in law. In Turkish law, for example, ipso facto clauses are generally acknowledged and applied in practice but the law is silent on their enforceability. Insolvency practitioners or liquidators will, guided by convention or practice, not law, approach creditors with a view to resolving potential disputes over the exercise of ipso facto clauses. $^{30}$ That does not however mean that there is no judicial intervention. In exceptional cases where the invoking of the ipso facto clause would conflict with a judicially sanctioned scheme of arrangement, the court would restrict its application by setting appropriate conditions.

30 See footnote 9 of Chapter 24 (infra). 
1.43 Countries which have expressly restricted or prohibited the use of ipso facto clauses include the US, France, Greece, Denmark, Germany, the UAE, Canada, Australia, Austria, Spain to name a few. There are a few observations to be had. First, although in most of these countries the rationale is for the preservation of the company so as to encourage rescue, the scope of the proscription differs from jurisdiction to jurisdiction. Some countries like Austria link the prohibition on ipso facto clauses to an automatic stay or suspension of contracts. Others like Spain do not enforce the ipso facto clause but presume that the contracts shall continue to be performed until an express application is made by the liquidator or administrator to terminate an economically onerous relationship. The other party does not have the right to terminate the contract. Secondly, most of these countries provide for exceptions to the general proscription. These exceptions may lie in contractual relationships where performance is virtually uneconomic and impacts on security interests (such as close-out netting, and other financial contracts), or impinges on personal liberties (such as employment contracts, and contracts of a personal services), or is impossible (such as contracts for derivatives). Thirdly, the scope of the ban on ipso facto clauses is not always fully formed given that in a number of countries, the prohibition had stemmed from recent reforms. There is little clarity as to the general principles which would be taken to bear on any decision as to the scope and interpretation of the prohibition and its exceptions.

\section{Assignment of executory contracts}

1.44 A related matter is how and to what extent assignment of the executory contract to a third party should be factored in the law relating to executory contracts in insolvency. From our country reports, it is clear that not all countries have special rules dealing with assignment of executory contracts. Assignment of executory obligations has an important role alongside the provision for assumption of contracts in insolvency. It can assist in the further attempts at reorganising the corporate landscape. Where the contract is assigned (in some jurisdictions following the assumption of the contract by the liquidator), the corporate debtor might be able to avoid its contractual obligations since the performance would thence be taken over by the assignee whilst at the same time, prevent the original claimant from pursuing the legal claim against them. In the reorganisation process, it is not unforeseeable that an assignment will follow the sale of the debtor company's assets.

1.45 Often the matter is left to general law - after all, an assignment of a debt is not merely a matter of interest in insolvency law. We see this position in a number of common law countries. In the USA for example while the Bankruptcy 
Code provides for the circumstances when an assignment of an executory contract would be permitted, it does not set out defining the meaning of assignment. That latter is largely a matter for general civil law of obligations. It is difficult to generalise about civil law jurisdictions - in the case of Denmark, for example, the matter of assignment of executory contracts is given extensive legislative coverage.

In the interest of the collective creditors the Danish law therefore grants the right for the debtor-in-possession to assign the continued executory contract to the buyer of the business without consent from the contracting party. ${ }^{31}$ The right to assign can only be exercised as part of a transfer in the ownership of the business and not in a one-off asset sale. This all-or-nothing approach might be somewhat restrictive but one can understand the safeguarding and practical reasons for the constraint. After all, as the law makes explicit any such endeavour is to be for the collective interest of the creditors. The other practical constraint is that some contracts simply could not be transferred because of their distinctive, specific nature, i.e., if the contract can only be fully performed by the original contracting party. On the whole a transfer or assignment can be done without consent (save in those where by their legal nature, the contracts could not be performed by another party without cooperation and consent from the original contracting party).

On the other hand, Russia - an assignment is permitted but its control seems very much to be a matter of judicial discretion. It appears to this editor that much of insolvency litigation in Russia is guided by legal rules which are often imprecise allowing for practical and policy considerations to be taken into account when judicial decisions are made. That seems to be the case as regards executory contracts and the matter of assignment of contracts. There is a significant degree of expectation that any scheme should pass the good faith test. ${ }^{32}$ That is a test in the general civil law, and not some insolvency law notion. On that basis, it might be suggested that in civil law jurisdictions, at least in theory, regard may be had to notions of transparency, honesty, and loyalty to the contractual relationships. The latter is often equated also with ensuring an equilibrium in the contractual relationship or discouraging opportunism. ${ }^{33}$

31 Danish Bankruptcy Act, s 14 c (2).

32 The Civil Code of Russian Federation, art 1.

33 See Saul Litvinoff, 'Good Faith' (1996) 71 Tulane Law Review 654, 675; Simon Whittaker and Reinhard Zimmerman, 'Good Faith', in Reinhard Zimmermann and Simon Whittaker (eds), European Contract Law: Surveying the Legal Landscape (CUP 2000), 7-62; Martijn W. Hesselink, 'The Concept of Good Faith', in Arthur S. Hartkamp, Martijn W. Hesselink et al. (eds), Towards a European Civil Code-Fourth Revised and Expanded Edition, (Kluwer Law International 2010), 619-49. 
1.48 The practical difficulty is that in urgent times when a distressed company needs to be reorganised, dealing with the question of validity of the assignment after the event is usually self-defeating. A more efficient way is for the assignment to be made subject to prior judicial approval. It is however not often clear in some legal systems whether prior approval is actually required. Where permitted, it might be useful for the office holder to seek judicial approval for the purported assignment.

1.49 Practicalities undoubtedly play an important role in positing the role of assignment in a corporate reorganisation exercise. In the case of the PRC, where the law is not very explicit about the treatment of executory contracts, assignment of the contracts to third parties (subject to the governance of the general principle of good faith and Government policy) might justifiably be seen as a practical means to avoid having to litigate the niceties of executory contracts and attendant contractual stipulations such as ipso facto clauses. The advantage with assignment as a device to help with the reorganisation exercise is that assignment is usually properly provided for by general contract law and no change to any insolvency law is needed.

1.50 In common law countries, there is, as to be expected, varying degrees of prescription as to the scope of the power of assignment. What seems obvious is that there is due recognition of the role of assignment in the reorganisation of the distressed company. However most such assignments will require judicial supervision or approval. In Canada, for example, the law is expressed in these terms: the court 'may make an order assigning the rights and obligations of a bankrupt under the agreement to any person who is specified by the court and agrees to the assignment'. ${ }^{34}$ Judicial approval in the Canadian context is dependent on various factors, including whether the proposed assignment is approved by the monitor, whether the assignee would be able to perform the contractual obligations and whether it was appropriate to assign the rights and obligations to that person. There is much scope thus for judicial discretion - but that is discretion guided by more general principles of creditor protection, asset protection and perhaps wider policy considerations. That said, the last is not explicitly expressed by court decisions or the legislation itself but from the tenor of the language of the law (the use of the word 'appropriate') the legislative intent is clearly not to be over restrictive as to what factors would be considered in giving approval for the assignment. Judicial

34 Bankruptcy and Insolvency Act 1985, s 84 (1). See too Companies' Creditors Arrangement Act 1985, s 11(3) where court approval for assignments in large scale insolvencies is also required. 
approval however may not be required in all common law countries; however there may be grounds to challenge the assignment on equitable grounds. ${ }^{35}$

Both common law and civil law countries tend generally to have restrictions on what contracts could be assigned. The subject is amply discussed in our country reports. However, in the interest of completeness, the topic of anti-assignment clauses merits examination.

At one level anti-assignment clauses might conceivably be treated as an equivalent to ipso facto clauses and they can certainly have a significant impact on the corporate reorganisation plans. That is especially so if the clause prevents the assignment not only of rights but also debts. Distressed companies could find it near impossible to seek receivable financing under those circumstances. In a UK context, a recent law was enacted to ban clauses which seek to prevent the assignment of receivables. ${ }^{36}$ That law does not ban anti-assignment clauses generally, only those clauses impacting on receivables. ${ }^{37}$ In gross, under the common law such clauses are valid.

In the USA, 11 United States Code $\$ 365$ provides for the power of the office holder to assign the executory contract to a third party. The legal position is also that any clauses preventing the assignment would usually not be enforced. There are exceptions to the general rule. One exception arises in contracts that are not assignable to third parties under applicable law and the party does not consent to such assumption or assignment. There is much literature and case

35 See e.g, England and Wales Insolvency Act 1986, para 74, Sch. B1 in the case of a company administrator's decision which unfairly prejudices one or a group of creditors. That said, without proper judicial guidance it is difficult to say what the scope and limits of judicial control might be.

36 Section 1 of the Small Business, Enterprise and Employment Act 2015 states:

'(1) The appropriate authority may by regulations make provision for the purpose of securing that any non-assignment of receivables term of a relevant contract-

(a) has no effect;

(b) has no effect in relation to persons of a prescribed description;

(c) has effect in relation to persons of a prescribed description only for such purposes as may be prescribed.

(2) A 'non-assignment of receivables term' of a contract is a term which prohibits or imposes a condition, or other restriction, on the assignment (or, in Scotland, assignation) by a party to the contract of the right to be paid any amount under the contract or any other contract between the parties.

(3) A contract is a relevant contract if-

(a) it is a contract for goods, services or intangible assets (including intellectual property) which is not an excluded financial services contract, and

(b) at least one of the parties has entered into it in connection with the carrying on of a business.'

37 For an account of the reasons for and against the legislative change, see Louise Gullifer, 'Should Clauses Prohibiting Assignment Be Overridden by Statute' (2015) 4 Penn St. JL E Int'l Aff. 47. See also Akseli Orkun, 'Contractual Prohibitions on Assignment of Receivables: an English and UN Perspective.', (2009) 7 Journal of Business Law 650. 
law as to the meaning and scope of 'applicable law'. ${ }^{38}$ It suffices to say that despite inconsistent judicial practice, there is inclination to construe 'applicable law' narrowly so as not to defeat the assignment of executory contracts. The US courts also make a distinction between what is non-assignable and what is non-delegable. ${ }^{39}$ Pulley writes, 'Ostensibly, the rationale for distinguishing non-delegable, or personal service, contracts from other contracts is that these laws generally give the party receiving or rendering performance the option to refuse an alternate performer, rather than making the refusal automatic.' 40

1.54 At this juncture it might be useful to reproduce the relevant USC provision, s 365c:

the trustee may not assume or assign any executory contract or unexpired lease of the debtor, whether or not such contract or lease prohibits or restricts assignment of rights or delegation of duties, if-

(1) (A) applicable law excuses a party, other than the debtor, to such contract or lease from accepting performance from or rendering performance to an entity other than the debtor or the debtor in possession, whether or not such contract or lease prohibits or restricts assignment of rights or delegation of duties; and

(B) such party does not consent to such assumption or assignment ...

1.55 In the US, there is also the vexed issue as to whether the 'applicable law' in question means that where such a law exists, not only the assignment but also the assumption of the executory contract is made impossible. Naturally the matter is largely a question of the interpretation of the US statute in question. From a functional comparative analysis, it suffices to observe that to interpret the law as extending to both assignment and assumption, from a policy standpoint, would be to place non-debtors on a stronger footing than debtors. Although that per se is not objectionable (in that the non-debtor had not asked to be made a party to the proceedings in the first place), favouring the non-debtor over debtors could well disturb the rationale which is intended to support the debtor in their reorganisation plans. ${ }^{41}$ It would seem to permit a creditor, at will, to pull out of the contract which, under normal circumstances, had been properly assumed on the basis of a technical ban. Thus, in a majority

38 See generally the literature reviewed in Theresa R. Pulley, 'Limitations on Assumption and Assignment of Executory Contracts by Applicable Law’, (2001) 31 New Mexico L. Rev. 299.

39 'At [US] common law, many courts interpreted "applicable law" under section [365](c)(1) to apply only to non-delegable, personal service contracts. Thus, even if a law existed that prohibited assignment, that law might not be sufficient to prohibit assumption and assignment under section (c)(1).' Pulley (ibid.) at p 309.

40 Ibid.

41 Ibid., at 314. 
of decisions in the US, the view is that unless assignment is actually contemplated, assumption of the contract would not be prevented. That said, such a constraint does not seem to have surfaced in other jurisdictions.

In Nordic and Baltic states, there is an influential academic commentary ${ }^{42}$ calling on the recognition of the right of the insolvent company to assign the executory contracts but subject to certain limitations. These limitations might be said to reflect an emerging consensus that such measures can assist in the reorganisation efforts of the company but should be practicable and be based on good faith. The Nordic-Baltic Recommendations on Insolvency Law, ${ }^{43}$ as the commentary is titled, recommends that an assignment should be enforced when:

- The insolvent has declared its intention that the contract should be continued (namely, the contract is assumed);

- It is reasonably clear that the assignee will be able to perform those obligations; and,

- The counterparty would not be substantially disadvantaged by the assignment. ${ }^{44}$

The Recommendations go on to suggest that contractual terms which seek to limit the general right of the insolvent to assume, disclaim and assign executory contracts should have no effect. Although the Recommendations do not have legally binding force, it is important to stress that in those Baltic and Nordic countries where there are no explicit provisions on the subject, these recommendations do have their origin in a good number of important commentaries and legal treatises.

It is difficult to envisage any legal system not permitting assignment of executory contracts - however, it must not be forgotten that not all legal systems define executory contracts in exactly the same way as we have discussed above.

\section{Value extraction}

Preserving value is clearly needful. However, in the cut and thrust corporate world there are 'investors' who seemingly step in to rescue the financially distressed company with a less than savoury agenda. These predatory investors

42 Produced by the Nordic-Baltic Insolvency Network.

43 The Recommendations (Wolters Kluwer 2016) are available here http:/www.sccl.se/wp-content/uploads/ 2017/04/Nordic-Baltic-Recommendations-Final-Version-bok-rotated.pdf.

44 See paras $15-16$. 
through setting up complex investment vehicles or arrangements may be entitled to extract in full or in part the value of their investment back and to strip the company's assets before the company eventually goes into an insolvency process. This prolonging of the company's demise and subsequently depletion of the corporate assets can undoubtedly lead to even greater damage to creditors and employees. There is little comparative law work on this subject which is increasingly troubling governments. This work goes a little distance to demonstrate that the matter of value preservation should not be considered in a discrete manner - value preservation has to be placed in a longer term context. ${ }^{45}$ In the UK, in March 2018 a consultation was launched to invite comments on a proposal to claw back such financial gains from investors who have extracted value in this manner. The Consultation Paper gives some examples of such value extraction arrangements: management fees; excessive interest on loans, charges over company property being granted; excessive director pay or other payments; or sale and leaseback of assets. ${ }^{46}$ These types of transactions may unfairly benefit certain parties whilst putting creditors in a worse position than they would otherwise have been in should that company subsequently become insolvent.

1.60 While it could not be said that all such rescues would fail, the UK Government is concerned that if they do fail that other creditors and other stakeholders are treated fairly and should not have to be left in a worse off position. The challenge is thus not to ban such investments (whereby the investors assume control of the company and then assume existing contracts) but to ensure that any law to claw back unfair gains made by those investors is sufficiently clear in its scope of application. It will also be needful to show that the initial investment had actually not added real value to the company - that will be highly problematic, though. The question of real value is always a difficult one in law. There is also the problem of how insolvency practitioners or office holders can unpick those complex value extraction arrangements. Many will be watching the developments in the UK with interest in this regard. Although the subject falls outside the scope of our project on executory contracts, it is undeniable that executory contracts form only one cog in the larger wheel of the subject of corporate rescues.

45 See e.g., country reports from Australia, the USA, Denmark, Germany, and Singapore to name a few.

46 Insolvency and Corporate Governance Consultation Paper 2018 https://assets.publishing.service.gov.uk/ government/uploads/system/uploads/attachment_data/file/691857/Condoc_-_Insolvency_and_Corporate_ Governance_FINAL_.pdf at p. 14 . 


\section{CONCLUSION}

This Critique has sought to draw on the rich materials the national reports have produced. It is hoped that its analysis of the key legal (as against policy) themes has gone some distance to show that despite the policy concerns about reorganisation, rescue and the preservation of value in the context of executory contracts, the legal rules can in themselves lead to results which may not sit well with the policy objectives. This analysis has also demonstrated that policy objectives can sometimes be overreached by the trustees or supervising court. In common law jurisdictions, that notably arises when highly judicialised tests are devised and applied to deal with definitions and to guide the office holder's discretion and/or judicial supervision. A highly judicialised approach could inevitably lead to confusion and causes dispute and controversies. In some civilian legal systems, on the other hand, the overreaching occurs because judicial discretion and government influence are left unbridled - as insolvency laws in a good many of civil law countries tend to be fairly perfunctory, much is left to the good sense of the supervisory tribunals. Although that has the advantage of an experienced court ensuring that good faith and neutrality are maintained, in less developed or less well resourced jurisdictions, the system may lead to unfairness or arbitrariness.

Naturally there is no one right answer to any of the challenges discussed in this 1.62 Introduction. That is very much because a solution in one jurisdiction could and would not work well in another. The fact remains that whether we are referring to a civil law country or a common law one, insolvency law interacts and intersects with different established laws, private and public. That means any solution, whether simple or complex, is likely to produce a knock-on effect elsewhere in the wider body of law.

It is thus enriching for practitioners, policy makers and scholars of insolvency law to experiment with good practices elsewhere but they must always have an eye on the wider legal tapestry. The challenges we face are global but uniform global solutions are likely to be counterproductive unless other legal principles and rules are also properly accommodated.

In closing, the editors are especially grateful to the project team for their sterling work in producing such a readable volume of often technical material. 